\title{
Expression Profile of Wheat DNA Methyltransferases Genes in Egyptian Wheat (Triticum Aestivum) Varieties Under PEG Induced Dehydration
}

\author{
Mona M. Elseehy ${ }^{1}$ and Ahmed M. El-Shehawi ${ }^{1,2}$
}

\begin{abstract}
DNA methyltransferases are group of enzymes that add methyl group to cytosine in DNAs. Methylation regulates gene expression under normal conditions as well as in response to adverse conditions. DNA methyltransferases gene expression level was estimated in seven Egyptian wheat varieties; (Misr1, Giza168, Sakha94, Sids1, Gemmiza7, Gemmiza11, and Shandawel1) under drought induced by polyethylene glycol (PEG) using semiquantitative PCR of cDNA generated from total RNA. The seven tested varieties showed variations in four wheat DNA methyltransferase (Met) gene expression. Sids1 variety showed high expression level of Met1, Met2b, CMT, and Met3. The other varieties varied in Met gene expression levels. Met1 gene expression ranged from 66 to $47 \%$ of Sids1 gene expression, Met2b was 71 to $44 \%$ of Sids1 gene expression, CMT level ranged from 60 to $22 \%$ Sids1 gene expression Met3 expression was 78-21\% of Sids1 gene expression. The results concluded that, in sidsiratety wheat Mets activities responde faster to PEGinduced dehydration. Also, variation in Mets genes expression may be due to resistance variation of resistance of wheat varieties to abiotic stresses, such as heat, salinity and drought. Consequently, Met genes activities could be used in the evaluation of new wheat varieties and genetic manipulation of wheat resistance to biotic and abiotic stresses.
\end{abstract}

Key words: Gene expression- abiotic stress- wheat resistance.

\section{INTRODUCTION}

Wheat (Triticum aestivum) represents the most consumed food crop for the world population and, it is the top strategic winter crop (www.FOA.org). Wheat production and quality is highly affected by many factors including biotic and abiotic factors. Diseases and wheat varieties are the main biotic factors that have direct impact on wheat production. Abiotic stresses include drought, salinity, cold, heat and other environmeatal conclitions. Drought has direct impact on plant growth, normal development and production, it is responsible for food shortage, malnutrition and famine around the world, especially in the developing world (Shinozaki and Yamaguchi-Shinozaki 2007, Singh et al, 2017). In plants, drought tolerance is achieved through complicated processes (Diatchenko et al, 1996), which involves various biochemical and molecular responses that are directed by a many gene. Drought tolerance is achieved at molecular, genetic, and phenotypic levels to help the plants to keep specific levels of water and ions. During drought, the plants accumulate higher levels of proline, glycine betaine, soluble carbohydrates, and antioxidants. These molecules have an essential role to maintain the vital cellular functions (Boominathan et al, 2004, Matsumura et al, 2005, Velculescu et al, 1995, and Matsumura et al, 2006). Tolerance to drought also induces genes involved in cellular metabolism, cellular detoxification, cellular transport, signal transduction of transcription factors, and late embryogenesis abundant (Coemans et al, 2005). In addition, endogenous abscisic acid level increases under drought condition to protect plants from desiccation (Buitink et al, 2006, Audic and Claverie 1997).

\section{DNA methylation}

DNA methylation at the fifth carbon of cytosine to produce 5-methylcytosine $\left(\mathrm{m}^{5} \mathrm{C}\right)$ is one type of epigenetic modifications. In animals, methylation occurs at the $\mathrm{CpG}$ islands (dinucleotide) in the gene promoter (Kanel et al, 2013). On the other hand, in plants, methyl group is added at three different nucleotide contexts; $\mathrm{CpG}, \mathrm{CpNpG}$ and $\mathrm{CpNpN}$ ( $\mathrm{N}$ is $\mathrm{A}, \mathrm{T}$, or $\mathrm{C}$ ) (Akimoto et $a l, 2007)$. DNA methylation is carried out by a group of enzymes called DNA methyltransferases (Mets). The CpG island is methylated by DNA methyltransferase I (Met1) (Law and Jacobsen 2010, 7 Zilberman, 2017). Cytosine at the $\mathrm{CpNpG}$ sequence is methylated by the plant specific methyltransferase (Chromomethyltransferase 3, CMT3) (Han and Wagner, 2014).

DNA methylation plays an indispensible role in the regulation of various plant biological functions including normal cell growth and differentiation, plant development (9 Ikeuchi et al, 2015), genetic imprinting (4 Jones et al, 2001), cell senescence (11 Demeulemeester et al, 1999), regulation of plant growth via gene expression regulation and chromatin remodeling (Han and Wagner 2014). It also deeply involved in plant response to abiotic stresses (Yaish et $a l, 2018$ ), and metabolic regulation (Yong-Villalobosa et al, 2015). DNA methylation was reported inside the gene promoter sequences and both types modulate the gene expression level (Takatsuka et al, 2015).

\footnotetext{
${ }^{1}$ Department of Genetics, Faculty of Agriculture, Alexandria University

${ }^{2}$ Department of Biotechnology, Taif University, Taif, Saudi Arabia

Received November 15, 2018, Accepted December 11, 2018
} 
Several studies reported the relationship between the level of DNA methylation and the gene expression level. Hypermethylation of promoter sequences was reported to be associated with gene silencing (Saze et al, 2012). Also, hypermethylation of heterochromatin and noncoding RNA regions (Akimoto et al, 2007) was parallel to lower levels of gene expression. Abiotic stresses cause changes in DNA methylation of genomic sequences as well as transposable elements (Sahu et al, 2013). For example, in Arabidopsis, drought induced by polyethylene glycol (PEG) led to changes in DNA methylation. Sequences close to the transcription start site of drought responsive genes showed DNA hypermethylation (Colaneri and Jones, 2013). In another study on rice, drought tolerant genotypes showed faster response to drought in the form of differential methylation that was correlated with changes in gene expression (Wang et al, 2011). Study of methylation in the whole genome (methylome) has been used as genomic approach to study methylation changes in response to diseases, abiotic stresses, or plant starvation (Yong-Villalobosa et al, 2015, Yaish et al, 2018).

Because DNA methyltransferases carry out DNA methylation, they have central function in regulation of gene expression during normal growth, development as well as the response to biotic and abiotic stresses. Therefore, in this study the expression of DNA methyltransferases was investigated under dehydration conditions in Egyptian wheat varieties.

\section{MATERIALS AND METHODS}

\section{Wheat varieties and sample collections}

Seeds of seven Egyyptian commercial wheat varieties were obtained from Egyptian Ministry of Agriculture (Table 1). Seeds were surface sterilized and germinated in $0.5 \%$ water agar containing $10 \%$ polyethylene glycol (PEG-6000) for 10 days (Guo et al, , 2013; Elsiddig et al, , 2013). Shoots were collected, cleaned, and (lyophilized) under vacuum at $-58^{\circ} \mathrm{C}$. Dried samples were ground into fine powder with coffee grinder, stored at $-20^{\circ} \mathrm{C}$ until used for RNA isolation.

\section{Primer design}

Primers for wheat DNA methyltransferases were designed based on their published sequence (Dai et al, 2005). the full-length mRNA of Wheat tubulin primers was designed according to Nucleotide database (http://www.ncbi.nlm.nih.gov). Primer 3 plus was also designed easing the bioinformatics database (www.bioinformatics.nl/cgi-bin/primer3plus). Primers were synthesized by Macrogen and (http://dna.macrogen.com). their information as well as their sequence are summarized in Table (2).

Table 1. Egyptian commercial wheat (Triticum aestivum) varieties used in this study

\begin{tabular}{llll}
\hline NO & Variety & Main Characteristics & Status \\
\hline 1 & Misr1 & Resistant to stem rusts & New \\
2 & Giza168 & Resistant to three rusts, heat, and drought & Commercial \\
3 & Sakha94 & Resistant to three rust diseases & Commercial \\
4 & Sids 1 & $\begin{array}{l}\text { Resistant to yellow rust, susceptible to } \\
\text { leaf rust, heat tolerant, salinity tolerant }\end{array}$ & Commercial, (Upper \\
5 & Gemmiza 7 & Resistant to yellow and stem rust & Egypt) \\
6 & Gemmiza 11 & Resistant to three rust diseases & Commercial \\
7 & Shandawel1 & $\begin{array}{l}\text { High adaptation, resistant to the } \\
\text { three rust diseases }\end{array}$ & Commercial \\
& & & Commercial \\
\hline
\end{tabular}

Table 2. DNA primer sequence designed for cDNA synthesis and PCR amplification

\begin{tabular}{clc}
\hline Primer & \multicolumn{1}{c}{ Sequence 5'----3' } & PCR Product \\
\hline Tubulin & AGTGTCCTGTCCACCCACTC & 244 \\
Tubulin & TGAAGTGGATCCTCGGGTAG & \\
TaMET1-F & GGGAAAGCAGATCTGTGAAAAT & 460 \\
TaMET1-R & GAGAGGAATGCTAAAATCATCT & \\
TaMET2b-F & GATGCACTCCGATTGAAACTGCTT & 340 \\
TaMET2b-R & GCAACCGCTATGCTCAGACTATT & \\
TaCMT-F & GGTCCCTGACTATGCAATGTCCTT & 430 \\
TaCMT-R & CACACCCCACATAACACAACAGAT & 530 \\
TaMET3-F & CTCCACATCAACTCAATGTTT & 5 \\
\hline
\end{tabular}




\section{RNA isolation}

Total RNA was isolated using commercial Qiazol reagent. A volume of $1 \mathrm{~mL}$ of Qiazol (QIAGEN, CA, USA), was added to $8 \mathrm{mg}$ of lyophilized ground wheat leaf powder and mixed thoroughly. Chloroform, $(0.3$ $\mathrm{ml}$ ), was added to the mixture. Then, the mixture was then shaken briefly and then centrifuged for $15 \mathrm{~min}$ at $4^{\circ} \mathrm{C}$ and $13000 \mathrm{rpm}$. The supernatant was transferred to a new microfuge tube. RNA was precipitated by the addition of Lithium chloride (4 M final concentration), mixed, and kept overnight at $-20^{\circ} \mathrm{C}$. Samples were centrifuged for $15 \mathrm{~min}$ at $4^{\circ} \mathrm{C}$ and $12000 \mathrm{rpm}$, RNA was washed with $70 \%$ ethanol, air dried and dissolved in DEPC water. The quality of RNA was tested using agarose gel electrophoresis. Its concentration and purity were determined at $260 \mathrm{~nm}$ and the OD260/280 ratio.

\section{Synthesis of cDNA}

Total RNA, $2 \mu \mathrm{g}$, were mixed with $0.5 \mathrm{ng}$ oligodT primer and the volume was completed to $11 \mu \mathrm{l}$ with sterilized DEPC water. RNA was denatured by incubated in the thermal cycler (Labnet, USA) at $65^{\circ} \mathrm{C}$ for $10 \mathrm{~min}$. Then, $4 \mu \mathrm{l}$ of $5 \mathrm{X}$ RT-buffer, $2 \mu \mathrm{l}$ of $10 \mu \mathrm{M}$ dNTPs and $100 \mathrm{U}$ M-MuLV Reverse Transcriptase (SibEnzyme. Russia) were added and mixed. The total volume was brought to $20 \mu \mathrm{l}$ by DEPC water. In the thermal Cycler the reaction was incubated at $37^{\circ} \mathrm{C}$ for $1 \mathrm{~h}$ for cDNA synthesis. The enzyme was inactivated by heating samples at $90^{\circ} \mathrm{C}$ for $10 \mathrm{~min}$ and the generated cDNA was kept at $-20^{\circ} \mathrm{C}$ until used .

\section{Semi-quantitative PCR}

PCR was carried out in a final volume of $25 \mu 1$ containing $1 \mu \mathrm{l}$ cDNA, $1 \mu \mathrm{l}$ of 10 picomol of forward and reverse primers, and $12.5 \mu \mathrm{l}$ PCR master mix (Promega, USA). PCR program was performed with one cycle of initial denaturation at $94^{\circ} \mathrm{C}$ for 5 minute for one cycle, followed by 20 cycles of denaturation at $94^{\circ} \mathrm{C}$ for $1 \mathrm{~min}$, annealing at $55^{\circ} \mathrm{C}$ for $30 \mathrm{~s}$, and extension at $72^{\circ} \mathrm{C}$ for $1 \mathrm{~min}$, and 1 cycle of final extension at $72^{\circ} \mathrm{C}$ for 5 min. Wheat tublulin mRNA was tested as a reference using its specific primers (Table 2). PCR products were separated at 100 volt for $1 \mathrm{~h}$ on $1.5 \%$ agarose gel and TAE buffer. Gels were stamed with ethiclium bromide, visualized with UV light and photographed. Band intensities were estimated using $\mathrm{NIH}$ image program (http://rsb.info.nih.gov/nih-imageJ).

\section{RESULTS}

Semiquantitative PCR was employed to investigate the mRNA expression of methyltransferases genes in seven Egyptian wheat varieties in response to PEG induced dehydration. Total RNA was used to generate
cDNA which was used as a template for PCR using specific primers for 4 methyltransferases genes (Table 2). The expression of wheat tubulin mRNA was estimated as reference in all experiments in this study (Figure 1b, 2b, 3b, 4b). In the seven tested varieties the specific primers of methyltransferase I (Met 1) genes amplified one fragment of $460 \mathrm{bp}$ (Figure 1a). As shown in Figure1c, the gene expression of Met1 gene in response to PEG induced dehydration varied from one variety to another. The highest level of Met1 gene expression was receded for eSid1 variety. Both Gemmiza7 and shandawel 1 illustrated very close expression of Met1 gene that was estimated as $66 \%$ of Sids1, Misr1, Giza168 and Sakha94 showed also close expression level that represented $57 \%, 55 \%$ and $53 \%$ of Sids1 expression, respectively. The lowest level of Met 1 gene expression was for Gemmiza11 (47\% of Sids1) expression.

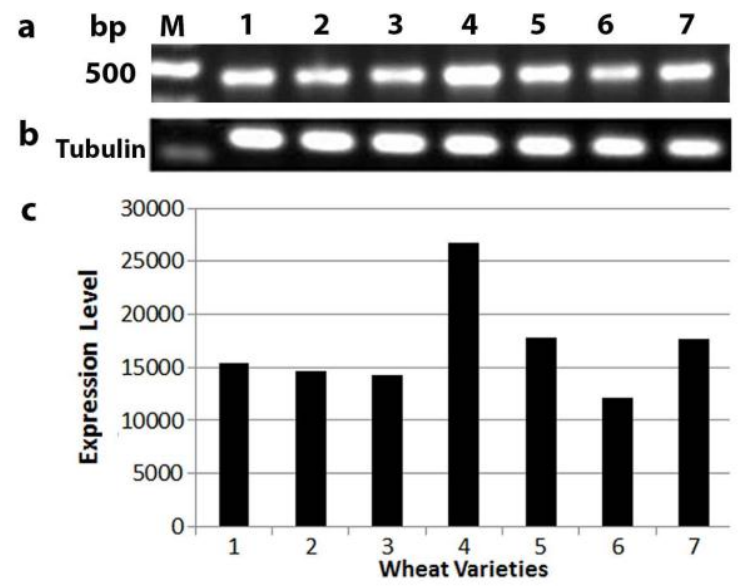

Figure 1. a. Agarose gel electrophoresis of RT-PCR products of wheat DNA methyltransferase 1 (Met1)gene. 1: Misr1, 2: Giza168, 3: Sakha94, 4: Sids1, 5: Gemmiza7, 6: Gemmiza11, 7: Shandawel1. b. Wheat tubulin gene expression. c. quantitative estimation of Met1 gene expression for the seven wheat varieties understudy under drought induced by PEG

PCR using wheat methyltransferase 2b (Met2b) specific primers amplified DNA fragment of bout 340 bp. in all tested varieties (Figure 2a). The semiquantitative analysis of wheat methyltransferase $2 b$ (Met2b) gene revealed different expression profile in response to PEG induced dehydration (Figure 2c). The highest level of Met2b gene expression was reported also for sidsl variety. In contrast, Sakha94 showed the lowest level of Met2b gene expression which was about $44 \%$ of Sids1, expression Giza 168 and Gemmiza11 had similar expression level (about $71 \%$ of Sids 1 expression 
level). Met2b gene expression for Shandawel1, Misr1 and Gemmiza7 varieties showed $66 \%, 58 \%$ and $50 \%$ of Sids1 expression level (Fig. 2c).

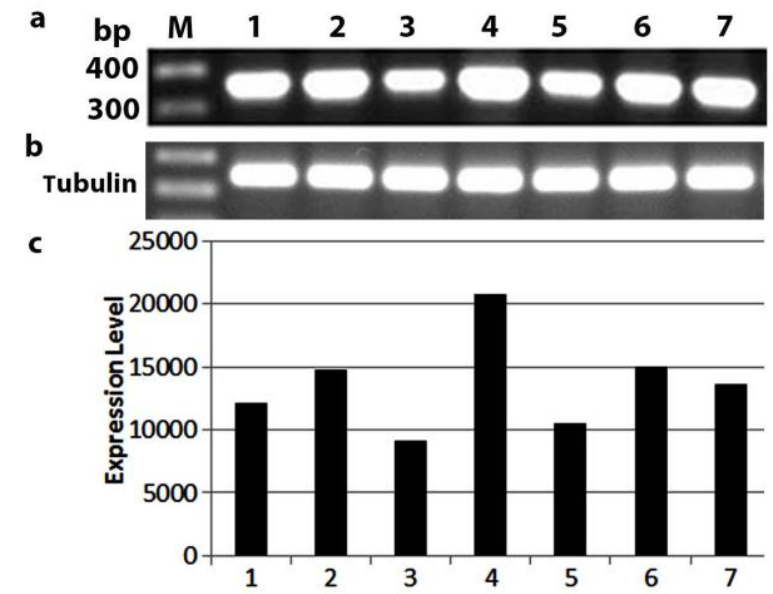

Figure 2.a. Agarose gel electrophoresis of RT-PCR products of wheat methyltransferase $2 b$ (Met2b). 1: Misr1, 2: Giza168, 3: Sakha94, 4: Sids1, 5: Gemmiza7, 6: Gemmiza11, 7: Shandawel1. b. Wheat tubulin gene expression. c. quantitative estimation of gene expression for the seven varieties under drought induced by PEG

For CMT gene, The seven studied varieties showed one fragment of 430bp (Figure 3a). Semiquantitative estimation of CMT expression level revealed that Sids1 had the highest gene expression. As shown in Figure 3c, Giza168 and Gemmiza7 showed about $60 \%$ and 57\%, respectively of Sids1 expression level. The ther varieties (Misr1, Sakha94, Gemmiza11, Shandawell) illustrated extremely low level of CMT expression (about $22 \%$ of Sids1 CMT expression level).

For Met3 gene, 530bp fragment was detected for the seven varieties of wheat under drought induced by PEG. Quantitatively, Sids1 was proven to be the highest level of Met3 gene expression. Giza168 and Gemmiza7 represented moderate level of Met3 gene expression as $78 \%$ and $62 \%$ of Sids1 expression level. Shandawell variety showed about $58 \%$ of Sids1 expression level. Also, for Met3 gene expression Gemmiza11, Misr1, and Sakha94 showed illustrated extremely low expression levels of Mets gene as $29 \%, 22 \%$, and $21 \%$, respectively of Sids1 expression level (Fig. 4c).

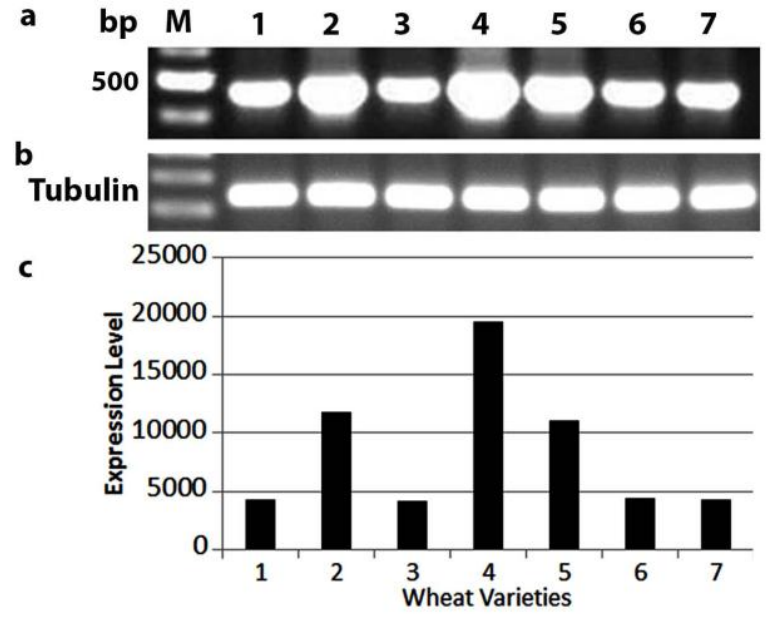

Figure 3. a. agarose gel electrophoresis of RT-PCR products of wheat CMT. 1: Misr1, 2: Giza168, 3: Sakha94, 4: Sids1, 5: Gemmiza7, 6: Gemmiza11, 7: Shandawel1. b. Wheat tubulin gene expression. c. quantitative estimation of gene expression for the seven varieties under drought induced by PEG

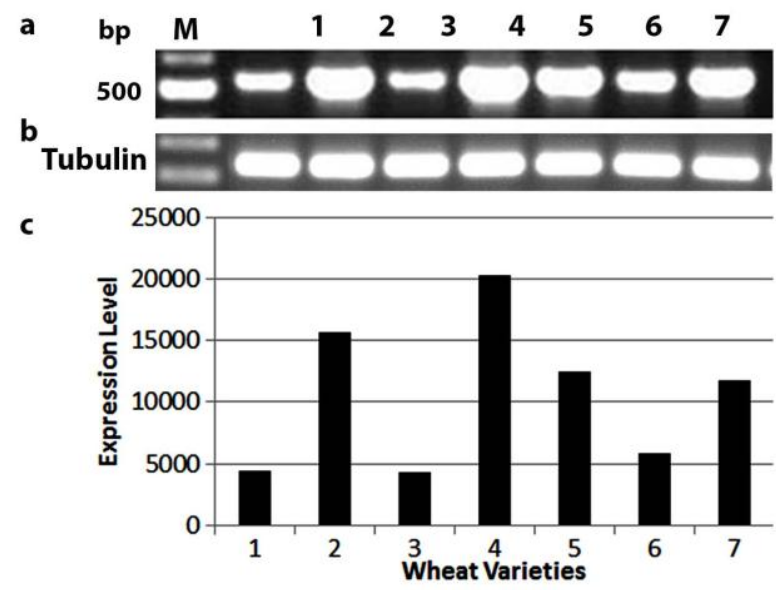

Figure 4. a. Agarose gel electrophoresis of RT-PCR products of wheat DNA methyltransferase 3 (TaMet3). 1: Misr1, 2: Giza168, 3: Sakha94, 4: Sids1, 5: Gemmiza7, 6: Gemmiza11, 7: Shandawel1. b. Wheat tubulin gene expression. c. quantitative estimation of gene expression for the seven varieties under drought induced by PEG

\section{DISCUSSION}

It is noteworthy that the Egyptian commercial wheat varieties used in this study differ in their resistance to rust diseases, heat, drought, and salinity. These differences could be a reason for their various Met gene expression. Sids1 variety is susceptible to leaf rust, whereas Shandawel1 is resistant to the three rust diseases. 
Using specific primers, the expression of four wheat DNA methyltransferases (Met) genes were investigated in seven Egyptian wheat varieties under drought induced by PEG. For each gene, one fragment with different DNA > >> and expression was detected Met1 and Met2b showed less general variations among the seven varieties. Interestingly, Sids1 variety presented the highest level of expression for the four tested wheat Mets. The activity of Mets and consequently DNA methylation may be contributed to its resistance to the biotic and abiotic stresses. Giza168 had moderate expression of Met3, whereas the other 5 varieties had low level of Met3 expression. Therefore, Met3 may be responsible for the de novo methylation in response to biotic and/or abiotic factors (Sahu et al, 2013). For Sids1 and Giza 168 varieties. Similar result was obtained for rice, where the drought tolerant genotypes responded faster to drought comparing to normal genotypes. The fast response of drought tolerant genotypes was correlated with differential methylation of drought induced genes. The methylation sites remained after removal of the stress as a methylation marks (Wang et al, 2011). Also, the two varieties (Sids1 and Giza168) had high level and moderate level of CMT that is responsible for the de novo methylation of $\mathrm{CpNpG}$ sequence. The other 5 investigated varieties are resistant to one or more type of rust (biotic stresses) and presented high expression levels of other Met genes. Misr1, while, Gemmiza7, and Shandawel1 recorded moderate expression of Met1, Gemmiza11 showed moderate expression level of Met2b, whereas Sakha94 showed low expression of the four Met genes. It could be concluded from the results of this study that Giza168 and Sids1 varieties (resistant to abiotic factors; heat, salinity and drought) had high Met3 gene expression level, whereas other varieties which are resistance to rust diseases had moderate levels of other Mets genes (Met1, Met2b, CMT) than Met3 that is gene this conclusion is supported by the normal function of Met genes. Met1 maintain methylation after DNA replication at the $\mathrm{CpG}$ sites, whereas the $\mathrm{CpNpG}$ methylation is maintained by CMT in plants (Han and Wagner 2014). Met2b is a tRNA methylatransferase enzyme, which does not has DNA methylation activity (Jeltscha et al, 2017). In contrast, Met3 enzyme is responsible for the de novo methylation in response to biotic and abiotic factors. Therefore, Met3 gene expression level could be used to differentiate between varieties in response to PEG induced drought.

In several studies, however, abiotic stress has been linked to methylation/demethylation of DNA genomic sequences and DNA methyltransferases activity (Sahu et $a l$, 2013). In arabidopsis, PEG induced dehydration led to change in DNA methylation (hypermethylation) near the transcription start site of dehydration responsive genes (Colaneri and Jones, 2013). Also in Arabidopsis, de novo DNA methylation caused by dehydrated environment caused the suppression of stomata development genes (Tricker et al, 2012, 2013). Promoter hypermethylation in Arabidopsis callus and suspension culture suppressed gene expression through hypermethylation of the $\mathrm{CpG}$ dinucleotide. The methylation was dependent on MET1 and DRM2 DNA methyltransferases (Berdasco et al, 2008).

Expression of DNA methyltransferases genes has been studied by several authors. For example, Wheat (Triticum aestivum) has several DNA methyltransferases (Mets). Five Mets were isolated including TaMET1, TaMET2 (TaMET2a, TaMET2b), TaCMT and TaMET3. They presented different expression levels in various wheat tissues (Dai et al, 2005). TaMET1 and TaMET2a had high expression in the dry seed, whereas TaMET1 and TaCMT had high expression level in embryos. Also, TaMET2b, TaCMT, TaMET1 showed expression in the same developing stages. Results of this study indicated that wheat DNA methyltransferases have critical role in wheat normal growth adaptation to biotic as well as abiotic stresses (Dai et al, 2005). On the other hand, in Arabidopsis, only 3 DNA Mets genes were found to be responsible for the maintenance and de novo DNA methylation (Moritoh et al, 2012, Zhang et al, 2006, Kurihara et al, 2008).

Finally, It is well known that DNA methylation/demethylation has indispensable role in dehydration tolerance. It contributes to plant resistance to abiotic stresses, such as drought; biotic stresses, such as disease resistance. Results obtained from this study will contribute to the evaluation of new wheat varieties for their Met gene expression and genetic manipulation to enhance resistance to biotic and abiotic stresses.

\section{REFRERENCES}

Akimoto, K., and H.Katakami, H. Kim, E. Ogawa, C. M. Sano, Y.Wada, and H.Sano, 2007 Epigenetic inheritance in rice plants. Annals of botany 100: 205-217

Audic S, and J.M.Claverie, 1997. The significance of digital gene expression profiles. Genome Res, 7:986-995.

Boominathan P, R. Shukla, A. Kumar, D. Manna, D. Negi, P.K. Verma, D.Chattopadhyay 2004. Long Term Transcript Accumulation during the Development of Dehydration Adaptation in Cicer arietinum. Plant Physiol, 135:1608-1620.

Buitink J, J.J. Leger, I. Guisle, B.L. Vu, S. Wuilleme, G.Lamirault, B.A Le, M.N. Le, A. Becker, H. Kuster, O. Leprince, 2006. Transcriptome profiling uncovers metabolic and regulatory processes occurring during the transition from desiccation-sensitive to desiccationtolerant stages in Medicago truncatula seeds. Plant J, 47:735-750. 
Coemans B, H. Matsumura, R. Terauchi, S. Remy, R. Swennen, L. Sagi 2005. SuperSAGE combined with PCR walking allows global gene expression profiling of banana (Musa acuminata), a nonmodel organism. Theor Appl Genet, 111:1118-1126.

Colaneri A.C., A. M. Jones 2013. Genome-wide quantitative identification of DNA differentially methylated sites in Arabidopsis seedlings growing at different water potential. PLoS One 8, e59878.

Dai Y, Z. Ni1, J. Dai, T. Zhao, Q. Sun, 2005. Isolation and expression analysis of genes encoding DNA methyltransferase in wheat (Triticum aestivum L.). Biochimica et Biophysica Acta 1729:118 - 125.

Demeulemeester, M., N. Van Stallen, and M. De Proft, 1999. Degree of DNA methylation in chicory (Cichorium intybus L.): influence of plant age and vernalization. Plant Sci. 142(1):101-8.

Diatchenko L, Y.F. Lau, A.P. Campbell, A. Chenchik, F. Moqadam, B. Huang, S. Lukyanov, K. Lukyanov, N. Gurskaya, E.D. Sverdlov, P.D. Siebert, 1996. Suppression subtractive hybridization: a method for generating differentially regulated or tissue-specific cDNA probes and libraries. Proc Natl Acad Sci USA, 93:6025-6030.

Han, S. and Wagner, D. 2014. Role of chromatin in water stress responses in plants. Journal of Experimental Botany. 65(10): 2785-2799.

Ikeuchi, M., A. Iwase, and K.Sugimoto, 2015. Control of plant cell differentiation by histone modification and DNA methylation. Curr Opin Plant Biol. 28:60-7.

Jeltscha, A., A.Ehrenhofer-Murray, T. P. Jurkowski, F.Lykoc, G.Reuterd, S.Ankri, W. Nellenf, M.Schaeferg, and M. Helmh, 2017. Mechanism and biological role of Dnmt2 in Nucleic Acid Methylation. RNA BIOLOGY 14(9):11081123.

Jones, L. F.Ratcliff, and D. C. Baulcombe, 2001. RNAdirected transcriptional gene silencing in plants can be inherited independently of the RNA trigger and requires Met1 for maintenance. Current Biology 11:747-757

Känel, T. and A. R. Huber, 2013. DNA methylation analysis. Swiss Med Wkly. 43:w13799

Kurihara, Y., Matsui, A., Kawashima, M. et al, 2008 Identification of the candidate genes regulated by RNAdirected DNA methylation. Biochem. Biophys. Res. Commun. 376, 553-557.

Law, J. A. and S. E. Jacobsen, 2010. Establishing, maintaining and modifying DNA methylation patterns in plants and animals. Nature Reviews Genetics. 11, 204-220.

Matsumura H, K.H. Bin Nasir, K. Yoshida, A. Ito, G. Kahl, D.H. Kruger, R. Terauchi: 2006. SuperSAGE array: the direct use of 26-base-pair transcript tags in oligonucleotide arrays. Nat Methods, 3:469-474.

Matsumura H, A. Ito, H. Saitoh, P. Winter, G. Kahl, M. Reuter, D.H. Kruger, R. Terauchi, 2005. SuperSAGE. Cell Microbiol, 7:11-18.
Moritoh S., C. Eun, E. Ono, H. Asao, Y. Okano, K. Yamaguchi, Z. Shimatani, A. Koizumi, R. Terada 2012. Targeted disruption of an orthologue of DOMAINS REARRANGED METHYLASE 2, OsDRM2, impairs the growth of rice plants by abnormal DNA methylation The Plant Journal 71:85-98

Sahu P.P., G. Pandey, N. Sharma, S. Puranik, M. Muthamilarasan, M. Prasad, 2013. Epigenetic mechanisms of plant stress responses and adaptation. Plant Cell Reports 32, 1151-1159.

Saze, H., K.Tsugane, T. Kanno, and T. Nishimura, 2012. DNA methylation in plants: relationship to small RNAs and histone modifications, and functions in transposon inactivation. Plant and Cell Physiology 53, 766-784.

Shinozaki K, and K. Yamaguchi-Shinozaki, 2007. Gene networks involved in drought stress response and tolerance. J Exp Bot 58:221-227 .

Singh D., C. K. Singh, J. Taunk, R.S.S. Tomar, A.K. Chaturvedi, K. Gaikwad, M. Pal, 2017. Transcriptome analysis of lentil (Lens culinaris Medikus) in response to seedling drought stress. Singh et al, . BMC Genomics (2017) 18:206 DOI 10.1186/s12864-017-3596-7

Takatsuka, H. and Umeda, M. 2015 Epigenetic Control of Cell Division and Cell Differentiation in the Root Apex. Front. Plant Sci. 6:1178.

Tricker P.J., J.G. Gibbings, C.M. Rodriguez Lopez, P. Hadley, M.J. Wilkinson. 2012. Low relative humidity triggers RNA-directed de novo DNA methylation and suppression of genes controlling stomatal development. Journal of Experimental Botany 63, 3799-3813.

Tricker P.J., C.M. Lopez, G. Gibbings, P. Hadley, M.J. Wilkinson. 2013. Transgenerational, dynamic methylation of stomata genes in response to low relative humidity. International Journal of Molecular Sciences 14, 66746689.

Velculescu V.E., L. Zhang, B. Vogelstein, K.W. Kinzler 1995. Serial analysis of gene expression. Science, 270:484-487.

Wang W.S., Y.J. Pan, X.Q. Zhao, D. Dwivedi, L.H. Zhu, J. Ali, B.Y. Fu, Z.K. Li. 2011. Drought-induced site-specific DNA methylation and its association with drought tolerance in rice (Oryza sativa L.). Journal of Experimental Botany 62, 1951-1960.

Wang, W. S. Y. J. Pan, X. Q. Zhao, D. Dwivedi, L. H. Zhu, J. Ali, B. Y. Fu, and Z. K. Li, 2011. Drought-induced sitespecific DNA methylation and its association with drought tolerance in rice (Oryza sativa L.). Journal of Experimental Botany 62, 1951-1960.

Yaish , M. W., A.Al-Lawati, I. Al-Harrasi, and H. V. Patankar, 2018 Genome-wide DNA Methylation analysis in response to salinity in the model plant caliph medic (Medicago truncatula). BMC Genomics. 19(1):78. 
Yong-Villalobos, L. S. I. González-Morales, K. Wrobel, D. Gutiérrez-Alanis, S. A. Cervantes-Peréz, C. HayanoKanashiro, A. Oropeza-Aburto, A. Cruz-Ramírez, O. Martínez, and L. Herrera-Estrella, 2015 Methylome analysis reveals an important role for epigenetic changes in the regulation of the Arabidopsis response to phosphate starvation. Proc Natl Acad Sci 112:52:E7293-302.
Zhang X, J. Yazaki, A. Sundaresan, S. Cokus, S.W. Chan, H. Chen, I.R. Henderson, P. Shinn, M. ellegrini, SE. Jacobsen, J.R. Ecker. 2006. Genome-wide high-resolution mapping and functional analysis of DNA methylation in Arabidopsis. Cell 126, 1189-1201.

Zilberman, D. 2017. An evolutionary case for functional gene body methylation in plants and animals. Genome Biology. 18:87.

\section{الملخص العربي}

\section{تعبير جينات DNA methyltransferases في أصناف القمح المصري (Triticum aestivum) تحت طEG ظروف الجفاف المستحدث بواسطة

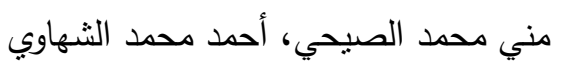

نفس الجينات في الصنف سدس ا، الجين Met1 أظهر

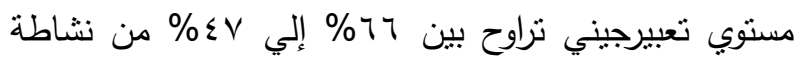
في الصنف سدس ا، الجين Met2b أظهر مستوي تعبير بين \% \% إلي §\% من نشاطة في الصنف سدس ا، الجين CMT أظهر نشاط تعبيري بين • ج\% إلي rr\% من مستوي تعبيره في الصنف سدس ا، وأخيرا الجين Met3 أظهر مستوي تعبير جيني بين \&>\% إلي اr\% من نشاطة في الصنف سدس l. نتائج هذه الدراسة تبرهن علي أن جينات Mets إيتلين جليكول في الصنف سدس ا، وأن الإختلافات في تعبير جينات Mets بين الأصناف المدروسة قد ترجع إلي إختلاف هذه الأصناف في مقاومتها للضغوط غير الحيوية منل الحرارة، الملوحة ، الجفاف. نتائج هذه الدراسة تساهم في تقييم أصناف القمح وكذللك في إنتاج أصناف محورة وراثيا لتحسين المقاومة للعوامل الغير حيوية.
مينات إضافة مجاميع الميثايل ميل تضيف مجاميع الميثايل علي السيتوسين في جزر (Mets) CpG الجيني تحت الظروف الطبيعية أو الظروف الغير مناسبة. في هذه الدراسة تم إستخدام سبعة أصناف تجارية من القمح

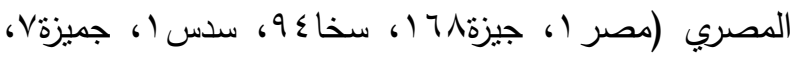
جميزة ( (، شندويل () لدراسة إستجابة جينات Mets للجفاف المستحدث بواسطة البولي إيتلين جليكول (PEG). تم إستخدام بادئات متخصصة لأربعة من جينات Mets في القمح (Met1, Met2b, CMT, Met3)، لتخليق جزيئات cDNA ) الكلي المستخلص من بادرات القمح مثبوعا بإستخدام RNA تفاعل PCR شبة الكمي. أظهرت نتائج الدراسة أنه يوجد إختلاف في تعبير جينات Mets في القمح، أظهر الصنف سدس ا نشاط أعلي للأربعة جينات التي تم دراستها، في حين أن الأصناف الأخري أظهرت درجات نشاط مختلفة من نشاط 